\title{
Seroprevalence of Transfusion Transmitted Infections among Blood Donors Attending a Tertiary Care Hospital of Western Odisha
}

\author{
Shuvankar Mukherjee ${ }^{1}$, Santosh Kumar Agarwal², Shreekant Tiwari ${ }^{3}$ \\ ${ }^{1}$ Department of Microbiology, Hitech Medical College, Rourkela, Odisha, India. ${ }^{2}$ Hitech Medical College, Rourkela, \\ Odisha, India. ${ }^{3}$ Department of Microbiology, Hitech Medical College, Rourkela, Odisha, India.
}

\section{ABSTRACT}

\section{BACKGROUND}

Blood transfusion is an important lifesaving intervention, but it poses the risk of transmission of different infections like hepatitis B, hepatitis C, human immunodeficiency virus (HIV), Treponema pallidum (causing syphilis) and Plasmodium spp. (causing malaria) to the recipient. Seroprevalence of different transfusion transmitted infection (TTI) among blood donors is an indirect measure of these infections in the community. This study was conducted to assess the seroprevalence of different TTIs in blood donors attending blood bank of a tertiary care hospital of Western Odisha.

\section{METHODS}

12,241 samples over 8 years from both voluntary and replacement donors were processed for HBsAg, HCV, HIV by ELISA method and for syphilis by RPR test, for malaria by rapid card test. Positive samples were confirmed by PCR method for HBsAg, HCV, HIV and by TPHA test for Syphilis and by peripheral smear study for malaria. All the positive samples were rejected for transfusion and the seroreactive blood donors were sent to appropriate department for treatment.

\section{RESULTS}

Among 12241 samples $0.96 \%$ (118/12241) samples were positive for TTI. $2.70 \%$ (328/12241) were voluntary donors and 1.87\% (229/12241) were female donors. Seroprevalence of hepatitis B, hepatitis C, HIV, Syphilis and malaria were 0.62, $0.044 \%, 0.073 \%, 0.1 \%$ and $0.12 \%$ respectively. Hepatitis $\mathrm{B}$ showed significant decrease of annual prevalence over 8 years.

\section{CONCLUSIONS}

Seroprevalence of TTI was lower compared to other studies of India. Highest seroprevalence was seen in hepatitis B. Awareness about hepatitis B vaccination should be increased in that area. Voluntary blood donation and female participation should be encouraged in that area.

\section{KEY WORDS}

Seroprevalence, TTI (Transfusion Transmitted Infections), Blood Donors, Trends
Corresponding Author: Shuvankar Mukherjee, Room No. 27, Staff Quarters, Hitech Medical College, Rourkela, Odisha, India

E-mail: shuvankar.mukherjee963@gmail.com

DOI: $10.14260 /$ jemds/2020/109

Financial or Other Competing Interests: None.

How to Cite This Article:

Mukherjee S, Agarwal SK, Tiwari S. Seroprevalence of transfusion transmitted infections among blood donors attending a tertiary care hospital of Western Odisha. J. Evolution Med. Dent. Sci. 2020;9 (08):483487, DOI: 10.14260/jemds/2020/109

Submission 24-12-2019,

Peer Review 29-01-2020,

Acceptance 05-02-2020,

Published 13-01-2020.

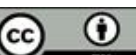




\section{BACKGROUND}

Blood transfusion is a lifesaving intervention in an accident, in case of anaemia and other haematological diseases. It was discovered by Dr James Bundell in 18181. Like all other medical interventions, it also has different adverse effects and risks. Most important risk is chances of acquiring transfusion transmitted infections. There is $1 \%$ chance of adverse effects including TTI with every unit of blood. ${ }^{2}$ Screening of blood Donors was first started in 1947.3 Government of India has started screening of blood unit for hepatitis B virus since 1971; HIV since 1989; hepatitis C virus since 2001.4,5 In spite of screening we cannot detect these diseases in their Window Period. Risk of getting blood within Window period of different diseases are 1 in 493000 in case of HIV; 1 in 103000 in case of hepatitis $C$ virus and 1 in 63000 in case of hepatitis B virus. ${ }^{6}$ India lies in an intermediate zone of HBV endemicity with prevalence of $2 \%$ to $8 \%$ in general population and $1 \%$ to $2 \%$ in blood Donors. ${ }^{7,8,9}$ There are about 50 million hepatitis $B$ virus carriers and that makes India the second largest pool of chronic hepatitis B virus carrier in the world. ${ }^{7}$

Seroprevalence of hepatitis $\mathrm{C}$ virus in blood donors in India is $0.12 \%$ to $2.5 \%$ and in general population it is less than $2 \%{ }^{10,11} \mathrm{HCV}$ prevalence is $3 \%$ in the world with 170 million people at risk. ${ }^{12}$ Global seroprevalence of HCV in blood donors is $0.4 \%$ to $19.2 \%$. The human immunodeficiency virus (HIV) is a retrovirus, an enveloped RNA virus, which is transmitted through parenteral and sexual route. It is found in blood and other body fluids. Target cell of HIV is lymphocyte where it replicates. The RNA of HIV integrates into the host cell DNA. HIV virus is classified into different groups and subtypes (Clades) that have significant antigenic differences; HIV-1 and HIV-2 are the two major distinct virus types and there is significant cross-reactivity between them. HIV-1 is endemic in many parts of the world including India. HIV-1 group M is responsible for most of the infections worldwide. The prevalence of HIV-2 is mainly restricted to West African region and India. Additionally, a few infections with HIV group $\mathrm{O}$ and group $\mathrm{N}$ have been observed in Africa. ${ }^{13}$ Seroprevalence of HIV in adult population is $0.26 \%$ in 2015 with 2.39 million people living with HIV or AIDS. ${ }^{14}$ There is about $1 \%$ of chance of getting HIV during blood transfusion. Seroprevalence of malaria and syphilis in blood donors are variable in different geographical area.

Transfusion transmitted infection not only cause morbidity, mortality in recipient but also it is a threat to his/her family and community as most of the TTI except malaria are sexually transmitted diseases. Estimation of TTI in blood donors is indirect indicator of disease burden in community as blood donors are asymptomatic individuals from community. Considering paucity of data about TTI in blood donors in Western Odisha we have conducted research to find out seroprevalence of different TTI in blood donors attending blood bank of a tertiary care hospital of Western Odisha.

\section{METHODS}

This prospective observational study was conducted in the blood bank of Hitech Medical College, Rourkela, in collaboration with Microbiology Department over a period of 8 years from Jan 2012 to Dec 2019 among replacement and voluntary blood donors. $2 \mathrm{ml}$ of blood was collected from all blood donors and serum was separated.

\section{Inclusion Criteria}

1. Healthy men and non-pregnant non lactating women.

2. Age 18 to 60 years,

3. Weight at least $45 \mathrm{~kg}$,

4. Haemoglobin levels at least $12.5 \mathrm{~g} / \mathrm{dL}$ (females) and 13.5 $\mathrm{g} / \mathrm{dL}$ (males)

5. No history of hepatitis B, hepatitis C, HIV, syphilis and malaria in patient.

6. No history of STD in sexual partners.

\section{Exclusion Criteria}

1. Professional donor.

2. Current history of taking any antibiotic, antiviral or antimalarial or antiretroviral therapy.

3. History of major surgery.

4. Blood transfusion within 1 years.

5. Radiotherapy or Chemotherapy (recent or past).

\section{Investigations}

1. Anti-HIV 1 \& 2 antibody ELISA (ERBA Lisa HIV Gen. 3)

2. HBsAg by ELISA (ERBA Lisa SEN HBsAg)

3. HCV Antibody ELISA (ERBA Lisa HCV Gen 3)

4. Syphilis RPR card test (Transasia).

Malaria card test (SD bio line) and positive samples were confirmed by peripheral smear method (Giemsa stain). All reactive samples for HIV, HBsAg, HCV were sent to PCR lab for confirmation. Syphilis was confirmed by TPHA test and malaria was confirmed by Peripheral smear study. All seropositive blood donors were sent to appropriate departments for treatment and they were rejected for blood donation.

\section{Data Analysis}

Data analysis was done by SPSS software version 21.

\section{RESULTS}

12241 samples were processed over 8 years period. Voluntary and Replacement blood donor's distribution was showed in Fig 1. Male and female distribution in different types of donors was showed in Fig 2. Prevalence of different TTI over 8 years was showed in Fig 3. Trends of different TTI over 8 years with annual prevalence was showed in Fig 4. Positivity of Different TTI according to age group was showed in Table 1. 

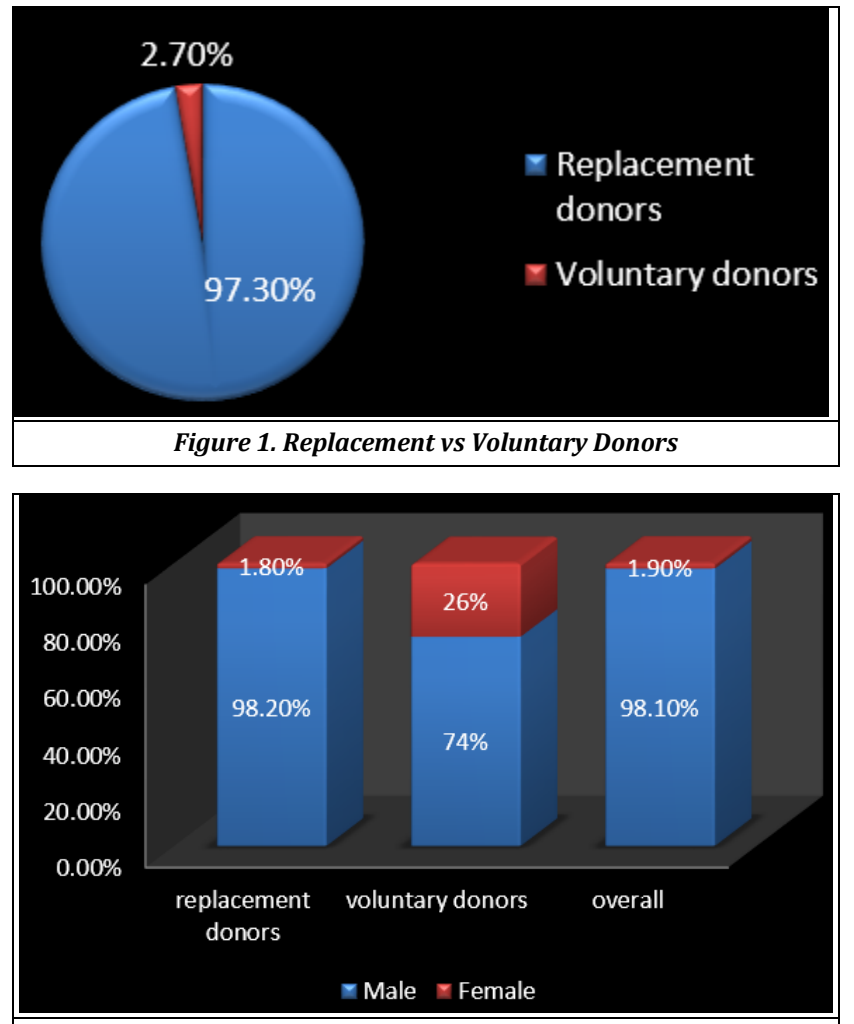

Figure 2. Sex Distribution among Different Types of Donors
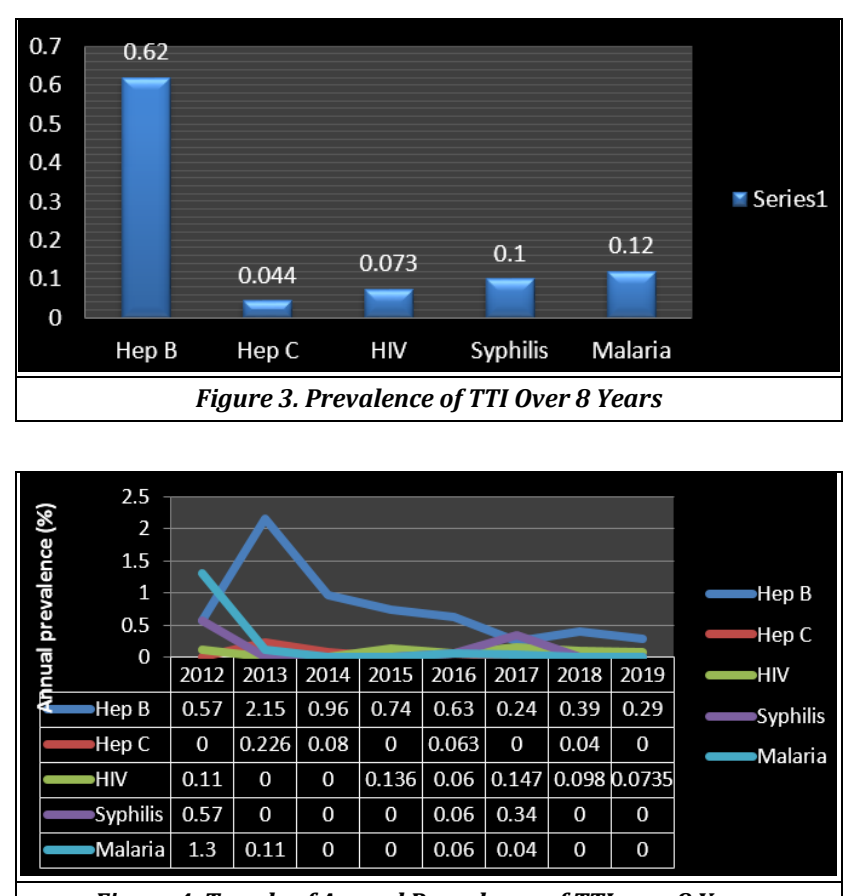

Figure 4. Trends of Annual Prevalence of TTI over 8 Years

\begin{tabular}{|c|c|c|c|c|c|c|c|}
\hline $\begin{array}{l}\text { Age } \\
\text { Group }\end{array}$ & $\begin{array}{c}\text { No. of } \\
\text { Donor } n \\
\text { (\%) }\end{array}$ & $\begin{array}{c}\text { HBsAg } \\
\text { Positive }\end{array}$ & $\mid \begin{array}{c}\text { HCV } \\
\text { Positive }\end{array}$ & $\begin{array}{c}\text { HIV } \\
\text { Positive }\end{array}$ & $\begin{array}{l}\text { Syphilis } \\
\text { Positive }\end{array}$ & $\begin{array}{l}\text { malaria } \\
\text { Positive }\end{array}$ & $\begin{array}{c}\text { Total } \\
\text { Positive }\end{array}$ \\
\hline$<20$ & $1236(10 \%)$ & $5(6.1 \%)$ & $0(0 \%)$ & $0(00)$ & $0 \times 0 \%$ & $1(7 \%)$ & $6(5.02 \%)$ \\
\hline $21-30$ & 52560 & 283 & $4(8$ & 61 & 91 & $8(53 \%)$ & 55 \\
\hline $31-40$ & $4112(34 \%)$ & $40(53 \%)$ & \begin{tabular}{|l|}
$1(20 \%)$ \\
\end{tabular} & $3(33 \%)$ & $4(3$ & $5(33 \%)$ & $53(45 \%)$ \\
\hline $41-50$ & $1637(13 \%)$ & $3(3.9 \%)$ & $0(0 \%)$ & $0(0 \%)$ & $0(0$ & $1(7 \%)$ & $4(3.38 \%)$ \\
\hline $51-60$ & $0(0 \%)$ & $0(0 \%)$ & $0(0 \%)$ & $0(0 \%)$ & $0(0 \%)$ & $0(0 \%)$ & $0(0 \%)$ \\
\hline Total & $\begin{array}{l}12241 \\
(100 \%)\end{array}$ & $\begin{array}{c}76 \\
(100 \%)\end{array}$ & \begin{tabular}{c|}
5 \\
$(100 \%)$
\end{tabular} & $\begin{array}{c}9 \\
(100 \%)\end{array}$ & $\begin{array}{c}13 \\
(100 \%)\end{array}$ & $\begin{array}{c}15 \\
(100 \%)\end{array}$ & $\begin{array}{c}118 \\
(100 \%)\end{array}$ \\
\hline
\end{tabular}

\section{DISCUSSION}

Every blood transfusion poses risk for transmissible disease; thereby it is important to check every unit of blood before transfusion. Most common TTI in India are HBV, HCV, HIV, Syphilis and malaria. Chagas disease, HTLV and Cytomegalovirus can be transmitted through blood, but these are not common in India ${ }^{13}$. We had excluded donors below 18 years and above 60 years and most of the donors were male, still our study reflected the disease burden in community of Western Odisha.

In our study most of the samples were from replacement donors $(97.3 \%)$ only $2.7 \%$ were from voluntary donors. Voluntary blood donation (\%) in our study was very much smaller than study done by Bhaumik et $\mathrm{al}^{1}(91.8 \%)$, Bhawani et $\mathrm{al}^{15}(41.64 \%)$, Fernandes $\mathrm{H}$ et $\mathrm{al}^{16}(61.2 \%)$, Kaur et $\mathrm{al}^{17}$ (45\%). This area needed more no of blood donation campaign to increase voluntary blood donation. In our study $98.12 \%$ were male donors and $1.87 \%$ were female donors. This finding was comparable with study done by Qureshi et $\mathrm{al}^{18}\left(2.2 \%\right.$ female), Gopi et $\mathrm{al}^{19}$ (2.84\% female), Biswal et $\mathrm{al}^{20}$ ( $0.92 \%$ female) Ray et $\mathrm{al}^{21}(0.22 \%$ female) but not consistent with the study done by Karmakar et $\mathrm{al}^{22}$ (15\% female) and Panda et $\mathrm{al}^{9}$ ( $8.3 \%$ female). However, in voluntary blood donation female participation was more $(26 \%)$ compared to replacement blood donation (1.80\%).This finding was consistent with the study done by Biswal et $\mathrm{al}^{20}$. In our study most of the donors were in age group of 21-30 (43\%) followed by age group of 31-40 (34\%) like another study by Gopi et al,19 Qureshi et al, ${ }^{18}$ Panda et al, ${ }^{9}$ Ray et al, ${ }^{21}$ Karmakar et al.22 Seroprevalence of TTI in our study was $0.96 \%$ which was higher than Agarwal et $\mathrm{al}^{23}(0.87 \%)$ but lower than Ray et $\mathrm{al}^{21}(3.22 \%)$, Karmakar et al $22(2.73 \%)$, Gopi et al ${ }^{19}(1.34 \%)$, Leena et $\mathrm{al}^{24}(1.35 \%)$, Amrutha et $\mathrm{al}^{25}(2.81 \%)$. Kotwal et al ${ }^{26}$ $(3.02 \%)$ and Kumar et $\mathrm{al}^{27}$ (4.57\%).

HBV seroprevalence was highest in our study compared to another TTI and it was consistent with most of the study worldwide. hepatitis $\mathrm{B}$ virus (HBV) is a member of the hepadnavirus group and is an enveloped DNA virus. HBV is transmitted through parenteral route and may be found in blood and other body fluids like semen and vaginal fluid. From the blood stream the virus travels to the liver as site of replication is hepatocytes. HBV is endemic globally and hyper-endemic in many parts of the world. While HBV is present in the bloodstream, the levels of the virus itself are variable. In recently infected individuals, viral DNA is normally present, although not always at high levels. Chronically infected individuals may either be infectious (DNA present) or non-infectious (viral DNA absent) and viraemia would generally be expected to be very low or absent entirely. ${ }^{13}$

HBV seroprevalence was $0.62 \%$ in our study which was almost similar to study done by Singh et al ${ }^{28}(0.62 \%)$,Gupta et $\mathrm{al}^{8}(0.66 \%)$ and Leena MS et $\mathrm{al}^{24}(0.71 \%)$.It was higher than Biswal et $\mathrm{al}^{20}(0.394)$ Qureshi et al ${ }^{18}(0.48 \%)$, Gopi et $\mathrm{al}^{19}$ $(0.098 \%)$, Shrestha et $\mathrm{al}^{29}(0.12 \%)$ but lower than study done by Amrutha Kumari25 (1.77\%) Kumar R et al ${ }^{27}$ (1.03\%), Panda et $\mathrm{al}^{9}(1.13 \%)$ Srikrishna et $\mathrm{al}^{30}(1.86 \%)$ Sastry et al ${ }^{31}$ $(1.23 \%)$ Bhattacharya et al $^{32}(1.66 \%)$, Bhaumik et al ${ }^{1}(1.2 \%)$ Karmakar et al ${ }^{22}(1.41 \%)$, Garg et al ${ }^{11}(3.44 \%)$, Pahuja et al ${ }^{10}$ (2.23\%), Chandra et $\mathrm{al}^{33}(1.96 \%)$, Arora et $\mathrm{l}^{34}(1.7 \%)$, Buseri 
FI et $\mathrm{al}^{35}$ (8.1\%) Terenpuntsag B et $\mathrm{al}^{36}(8.1 \%)$, Ray et $\mathrm{al}^{21}$ (1.36\%) Giri et al 37 (1.09\%).

Hepatitis C virus (HCV) is a member of the flavivirus group and is an enveloped RNA virus. It is transmitted through parenteral route and may be found in blood and other body fluids like vaginal fluid or semen. From the bloodstream, the virus travels to the liver where it replicates in hepatocytes, resulting in a similar picture to that seen with HBV infection. In our study hepatitis $C$ prevalence was $0.044 \%$ which was lower than study done by Leena et $\mathrm{al}^{24}$ $(0.14 \%)$, Amrutha et $\mathrm{al}^{25}(0.13 \%)$, Kumar et $\mathrm{al}^{27}(1.53 \%)$, Panda et $\mathrm{al}^{9}(1.98 \%)$, Srikrishna et al ${ }^{30}(1.02 \%)$, Sastry et $\mathrm{al}^{31}$ $(0.41 \%)$ Gopi et $\mathrm{al}^{19}(0.081 \%)$, Pallavi et al ${ }^{38}(0.23 \%)$, Gupta et $\mathrm{al}^{8}(1.09 \%)$, Pahuja et $\mathrm{al}^{9}(0.66 \%)$, Chandra $\mathrm{T}$ et $\mathrm{al}^{33}$ $(0.85 \%)$, Arora et $\mathrm{al}^{34}(1 \%)$, Bhattacharya et $\mathrm{al}^{32}(0.31 \%)$ Karmakar et al $22(0.59 \%)$, Shrestha et $\mathrm{al}^{29}(0.64 \%)$, Buseri FIetal 35 (6\%), Terenpuntsag B et $\mathrm{al}^{36}(8.7 \%)$.

In our study HIV prevalence was $0.073 \%$ which was almost similar to Giri et $\mathrm{al}^{37}(0.07 \%)$ and Gupta et $\mathrm{al}^{8}$ $(0.084 \%)$. But it was lower than study done by Leena MS et $\mathrm{al}^{24}(0.27 \%)$, Ray et al ${ }^{21}(0.56 \%)$,Kumar et al ${ }^{27}(0.26 \%)$, Panda et $\mathrm{al}^{9}(0.35 \%)$, Srikrishna et $\mathrm{al}^{30}(0.44 \%)$, Sastry et $\mathrm{al}^{31}$ $(0.28 \%)$, Gopi et $\mathrm{al}^{19}(0.16 \%)$, Pallavi et $\mathrm{al}^{38}(0.44 \%)$, Pahuja et $\mathrm{al}^{10}(0.56 \%)$, Chandra $\mathrm{T}$ et $\mathrm{al}^{33}(0.23 \%)$, Arora et $\mathrm{al}^{34}$ $(0.3 \%)$, Bhattacharya et $\mathrm{al}^{32}(0.28 \%)$, Karmakar et al ${ }^{22}(0.6 \%)$, Biswal et $\mathrm{al}^{20}(0.128 \%)$,Shrestha et $\mathrm{al}^{29}(0.12 \%)$, Buseri FI et $\mathrm{al}^{35}$ (3.1\%) and Amrutha Kumari ${ }^{25}$ (0.63\%). In our study Syphilis prevalence was $0.1 \%$ which was similar to Leena MS et al $24(0.129 \%)$ It was lower than Fernades $\mathrm{H}$ et al ${ }^{16}(2 \%)$, Kumar et $\mathrm{al}^{27}(1.74 \%)$, Srikrishna et $\mathrm{al}^{30}(1.6 \%)$,Gupta et $\mathrm{al}^{8}$ $(0.85 \%)$, Arora et $\mathrm{al}^{34}(0.9 \%)$, Bhattacharya et $\mathrm{al}^{32}(0.72 \%)$, Karmakar et al $22(0.23 \%)$, Biswal et $\mathrm{al}^{20}(0.706 \%)$,Buseri FI et $\mathrm{al}^{35}(1.1 \%)$, Amrutha kumari25 $(0.28 \%)$ It was higher than Sastry et $\mathrm{al}^{31}(0.008 \%)$, Gopi et al ${ }^{19}(0.024 \%)$ and Chandra T et $\mathrm{al}^{33}(0.01 \%)$. In our study malaria prevalence was $0.12 \%$ which was higher than Kumar et $\mathrm{al}^{27}(0.006 \%)$, Sastry et $\mathrm{al}^{31}$ $(0.0 \%)$, Fernades $\mathrm{H}$ et al $16(0.01 \%)$ but it was lower than Leena MS et $\mathrm{al}^{24}(0.129 \%)$, Biswal et al $20(0.113 \%)$, Buseri et $\mathrm{al}^{35}(30.2 \%)$, Ali MSM et $\mathrm{al}^{39}(16.5 \%)$.

About trend analysis gradual fall of annual prevalence was noted in case of hepatitis B but not in another TTI like Hepatis C and HIV. This gradual decrease in prevalence of HBV was also showed by Bhaumik et $\mathrm{al}^{1}$, Ray et $\mathrm{al}^{21}$ and Karmakar et al. ${ }^{22}$ Gopi et al ${ }^{19}$ had reported no significant changes of prevalence of HBV over years. Qureshi et al ${ }^{18}$ had reported decrease of both HBV and HCV prevalence over years. Karmkar et $\mathrm{al}^{22}$ had reported decrease of $\mathrm{HCV}$ prevalence only but not of HBV. Gradual decrease of HBV prevalence over recent years in our study might be due to increase in HBV vaccination in that area and increase awareness among general population about risky behaviour like blood transfusion, needle sharing, unsafe sex etc.

Although male donors and donors of age group of 20 to 40 were more affected with TTI in our study but it was not significant as no of male donors and donors of this age group was also larger compared to female donors and donors of another age group respectively?

\section{CONCLUSIONS}

Prevalence of TTI in our study (0.96\%) was lower compared to other studies of India. It might be due to good health status of blood donors as compared to general population, better lifestyle and effective impact of government program (like NACO for HIV). HBV was the most prevalent TTI in our study. So, there is need for initiating efforts for health programmes for HBV in addition to boosting universal immunization programs with HBV which was started in 2007 with more focus on youth population who are not vaccinated yet. Also, there is a need for organizing more number of blood donation camps to increase voluntary blood donation and female participation in blood donation should be encouraged.

\section{REFERENCES}

[1] Bhaumik P, Debnath K. Prevalence of blood-borne viral infections among blood donors of Tripura. Euroasian J Hepatogastroenterol 2014;4 (2):79-82.

[2] Widman FK. Technical manual. American Association of Blood Bank, Arington, 1985: p. 325-44.

[3] History of Blood Transfusions. http://www.redcrossblood.org/ learn-aboutblood/blood-transfusions/ history-blood-transfusion accessed on 18/5/2016.

[4] Narayan S. Microbes and blood transfusion. Indian J Med Microbiol 2001;19 (3):119-26.

[5] Makroo RN, Chowdhry M, Bhatia A, et al. Prevalence of HIV among blood donors in a tertiary care center of north India. The Indian Journal of Medical Research 2011;134 (6):950-3.

[6] Schreiber GB, Busch MP, Kleinman SH, et al. The risk of transfusion-transmitted viral infections. The Retrovirus Epidemiology Donor Study. N Engl J Med 1996;334 (26):1685-90.

[7] Datta S. An overview of molecular epidemiology of hepatitis B virus (HBV) in India. Virol J 2008;5:156.

[8] Gupta N, Kumar V, Kaur A. Seroprevalence of HIV, HBV, $\mathrm{HCV}$ and syphilis in voluntary blood donors. Indian J Med Sci 2004;58 (6):255-7.

[9] Panda M, Kar K. HIV, hepatitis B and C infection status of the blood donors in a blood bank of a tertiary health care centre of Orissa. Indian J Public Health 2008;52 (1):43-4.

[10] Pahuja S, Sharma M, Baitha B, et al. Prevalence and trends of markers of hepatitis $C$ virus, hepatitis $B$ virus and human immunodeficiency virus in Delhi blood donors: a hospital based study. Jpn J Infect Dis 2007;60 (6):389-91.

[11] Garg S, Mathur DR, Garg DK. Comparison of seropositivity of HIV, HBV, HCV and syphilis in replacement and voluntary blood donors in western India. Indian J Pathol Microbiol 2001;44 (4):409-12.

[12] WHO. Global surveillance and control of hepatitis C. Report of a WHO consultation organized in collaboration with the Viral hepatitis Prevention Board, Antwerp, Belgium. J Viral Hepat 1999;6 (1):35-47. 
[13] WHO. Screening donated blood for transfusion transmissible infections, Who.int.2019. [Cited 22 December

https://www.who.int/bloodsafety/ScreeningDonatedBl oodforTransfusion.pdf

[14] Ministry of Health \& Family Welfare Government of India. HIV Estimations 2015. Technical report. National AIDS Control Organisation and National Institute of Medical Statistics, ICMR. 2015.

[15] Bhawani Y, Rao PR, Sudhakar V. The seroprevalence of transfusion transmissible infection among the blood donors in a tertiary care hospital of Andhra Pradesh. Biology and Medicine 2010;2 (4):45-8.

[16] FernadesH, D'Souza PF, D'Souza PM. Prevalence of transfusion transmitted infection in voluntary and replacement donors. Ind J Hematol Blood Transfus 2010;26 (3):89-91.

[17] Kaur H, Manjari M, Thaman RG, et al. Prevalence of markers of hepatitis $\mathrm{C}$ virus among the blood donors. J Clin Diag Res 2012;6 (6):959-62.

[18] Qureshi MZ, Bashir H, Maroof P, et al. Seropositivity of hepatitis B Virus and hepatitis C Virus among blood donors at a tertiary care hospital in Kashmir: a ten-year study. Int J Cur Res Rev 2016;8 (19):17-20.

[19] Dobariya GH, Raja KA, Unagar CA, et al. Prevalence and trends of transfusion transmitted infections among blood donors of blood bank attached to government hospital of South Gujarat, India. Int J Res Med Sci 2016;4 (9):4123-7.

[20] Biswal M, Mohanty P, Panda P, et al. Prevalence of transfusion transmitted infections (ttis) amongst blood donors of North Odisha - a 8 years study. Int J Rec Sci $\begin{array}{lll}\text { Res } \quad 2018 ; 9 & \text { (5 } 26598-600 .\end{array}$ http://www.recentscientific.com.

[21] Ray K, Roy H, Das M. Trends of transfusion transmissible infections among blood donors in a rural medical college of West Bengal, India. Al Ameen J Med Sci 2018;11 (2):93-100.

[22] Karmakar PR, Shrivastava P, Ray TG. Seroprevalence of transfusion transmissible infections among blood donors at the blood bank of a Medical College of Kolkata. Indian J Public Health 2014;58 (1):61-4.

[23] Agarwal N. Response rate of blood donors in the Uttarakhand region of India after notification of reactive test results on their blood samples. Blood Transfus 2014;12 (Suppl 1):S51-3.

[24] Leena MS, Mohd. Shafee. Trend and prevalence of transfusion transmitted infections among blood donors in rural teaching institute, south India. Journal of Pathology of Nepal 2012;2 (3):203-6.

[25] Amrutha KB, Deepa S, Venkatesha D. Blood transfusions: are they life-saving or transfusing infections? Online J Health \& Allied Sci 2011;10 (2):7.
[26] Kotwal U, Doda V, Arora S, et al. Blood donor notification and counselling: our experience from a tertiary care hospital in India. Asian J Transfus Sci 2015;9 (1):18-22.

[27] Kumar R, Gupta S, Kaur A, et al. Sero-prevalence and changing trends of transfusion transmitted infections among blood donors in a tertiary care hospital. Indian J Comm Health 2015;27 (1):25-9.

[28] Singh K, Bhat S, Shastry S. Trend in seroprevalence of hepatitis B Virus infection among blood donors of Coastal Karnataka, India. J Infect Dev Ctries 2009;3 (5):376-9.

[29] Shrestha AC, Ghimire P, Tiwari BR, et al. Transfusion transmissible infections among blood donors in Kathmandu, Nepal. J Infect Dev Ctries 2009;3 (10):794-7.

[30] Srikrishna A, Sitalakshmi S, Damodar P. How safe are our safe donors? Indian J Pathol Microbiol 1999;42 (4):4116.

[31] Sastry JM, Agawane SU, Harke VA. Retrospective study of the five-year prevalence and trends of Transfusion Transmitted Infections (TTIs) among blood donors at a charitable hospital blood bank in Pune, India. International $\mathrm{J}$ of Healthcare and Biomedical Research 2014;2 (3):193-200.

[32] Bhattacharya P, Chandra PK, Datta S, et al. Significant increase in HBV, HCV, HIV and syphilis infections among blood donors in West Bengal, Eastern India 2004-2005: Exploratory screening reveals high frequency of occult HBV infection. World J Gastroenterol 2007;13 (27):37303.

[33] Chandra T, Kumar A, Gupta A. Prevalence of transfusion transmitted infection in blood donors: an Indian experience. Trop Doct 2009;39 (3):152-4.

[34] Arora D, Arora B, Khetarpal A. Seroprevalence of HIV,HBV, HCV and syphilis in blood donors in southern Haryana. Ind J Pathol Microl 2010;53 (2):308-9.

[35] Buseri FI, Muhibi MA, Jeremiale ZA. Seroepidemiology of transfusion transmissible infectious diseases among blood donors in Osoglor, southwest Nigeria. Blood Transfus 2009;7:293-9.

[36] Terenpuntsag B, Oupbileg L, Nelson K, et al. Prevalence of infectious diseases among Mangolian blood donors. J Infect Dev Ctries 2008;2 (1):73-5.

[37] Giri PA, Deshpande JD, Phalke DB, et al. Seroprevalence of transfusion transmissible infections among voluntary blood donors at a teaching Hospital in a rural area of India. J Fam Med Prim Care 2012;1 (1):48-51.

[38] Pallavi P, Ganesh CK, Jayashree K, et al. Seroprevalence and trends in transfusion transmitted infections among blood donors in a university hospital blood bank: a 5year study. Ind J Hematol Blood Transfus 2011;27 (1):16. Published online: 14 December 2010.

[39] Ali MSM, Kadaru AAGMY, Mustafa MS. Screening blood donors for malaria parasite in Sudan. Ethiop J Health Dev 2004;18 (2):70-4. 